\title{
LOW COST DRIVER DEVICE FOR MICROCLIMATE MAINTENANCE IN THE PRE- MILKING OF DAIRY CATTLE
}

\section{IRENILSON M. DA SILVA ${ }^{1}$, HÉLITON PANDORFI ${ }^{2}$, ÂNGELO J. S. DE VASCONCELOS ${ }^{3}$, RENATO LAURENTI ${ }^{2}$, CRISTIANE GUISELINI ${ }^{2}$}

\begin{abstract}
Due to the importance of the environment on animal production and thus environmental control, the study aims to build a system for monitoring and control the meteorological variables, temperature and relative humidity, low cost, which can be associated with an evaporative cooling system (ECS). The system development included all the stages of assembly, test and laboratory calibration, and later the validation of the equipment carried in the field. The validation step showed results which allowed concluding that the system can be safely used in the monitoring of these variables. The controller was efficient in management of the microclimate in the waiting corral and allowed the maintenance of the air temperature within the comfort range for dairy cattle in pre-milking with averaged $25.09{ }^{\circ} \mathrm{C}$ during the afternoon. The equipment showed the lower cost ( $\mathrm{R} \$ 325.76)$ when compared to other middle market ( $\mathrm{R} \$ 450.00)$.
\end{abstract}

KEYWORDS: dairy cattle, thermal comfort, instrumentation.

\section{DISPOSITIVO CONTROLADOR DE BAIXO CUSTO PARA A MANUTENÇÃO DO MICROCLIMA NA PRÉ-ORDENHA DE BOVINOS LEITEIROS}

RESUMO: Devido à importância do ambiente na produção animal e, portanto, do controle ambiental adequado, objetivou-se com este trabalho a construção de um sistema de monitoramento e controle das variáveis meteorológicas, temperatura e umidade relativa do ar, de baixo custo, associado a um sistema de resfriamento adiabático evaporativo (SRAE). O desenvolvimento do sistema controlador compreendeu as etapas de montagem, teste e aferição em laboratório e, posteriormente, a etapa de validação do equipamento realizada a campo. A etapa de validação apresentou resultados que permitiram concluir que o sistema pode ser utilizado com segurança no monitoramento e controle dessas variáveis por meio dos atuadores. O controlador mostrou-se eficiente no manejo do microclima no curral de espera e permitiu a manutenção da temperatura do ar dentro da faixa de conforto para bovinos leiteiros na pré-ordenha, apresentando média de $25,09^{\circ} \mathrm{C}$ durante o turno da tarde. $\mathrm{O}$ equipamento apresentou custo inferior ( $\left.\mathrm{R} \$ 325,76\right)$ quando comparado à média de outros no mercado $(\mathrm{R} \$ 450,00)$.

PALAVRA CHAVE: bovinocultura leiteira, conforto térmico, instrumentação.

\section{INTRODUCTION}

The dairy industry faces continuing challenges facing the Brazilian economy and still has problems from lack of information to neglect. One of the biggest limitations is the lack of automation capabilities for recording data in the field, leading to many risks to the profitability and sustainability in the sector (BOTEGA et al., 2008).

To ensure domestic supply and compete in the international market, livestock must have suitable efficiency and productivity indexes without neglecting environmental protection and activity monitoring (NASH et al., 2009). To achieve these goals, it becomes necessary to incorporate advances in automation and information technology in their products and processes. An automation project in livestock aims at meeting the various sectors of the activity, which comprises

\footnotetext{
${ }^{1}$ Mestre em Engenharia Agrícola, Universidade Federal Rural de Pernambuco.

${ }^{2}$ Professor Adjunto, Departamento de Tecnologia Rural, Universidade Federal Rural de Pernambuco.

${ }^{3}$ Engenheiro Agrícola, Universidade Federal Rural de Pernambuco.

Recebido pelo Conselho Editorial em: 30-8-2011

Aprovado pelo Conselho Editorial em: 4-8-2012
} 
the technological development of methods, techniques and tools in instrumentation, automation, information technology, systems integration, processes and data communication (ALVAREZ \& NUTHALL, 2006; SORENSEN et al., 2010).

In the tropics, a major problem in dairy cattle is the elimination of body heat to the environment. However, this factor is not related only to high temperatures, but the association of these with high humidity and low air movement. Climatic conditions in these regions are major challenges for producers by altering the three vital animal processes: maintenance, reproduction and milk production (ARCARO et al., 2006; MATARAZZO et al., 2006).

Most automation systems need some kind of interface that allows it to assess the current state of the system. This interface usually consists of sensors that measure environmental variables such as temperature, light intensity, level of certain gases in the air or moisture. The sensors detect the variables and transform them into an electrical pulse. This pulse is usually transmitted to a central controller, which responds to stimulation by a pre-set method and sends the information to the actuators (WATHES et al., 2008).

The automation of processes in dairy farms is still a reality only for large milk producers, with slow and gradual incorporation, justified by the constraints of funds availability for large investments.

Thus, this study was conducted with the objective of developing a low cost system for monitoring and controlling the meteorological variables (temperature and relative humidity) compared to models found in the market, which can be associated with an evaporative cooling system with emphasis on optimization of milk production.

\section{MATERIAL AND METHODS}

The study was conducted at the Department of Rural Technology, Rural Federal University of Pernambuco, Recife - PE, Brazil, comprising the steps of assembly, test and measurement of the controller system in the laboratory and then the validation step of the equipment carried out in the field.

The block diagram of the controller hardware for automating the control of the microclimate in the pre-milking of dairy cows can be observed in Figure 1. The term hardware applies to central processing unit, memory and input and output devices, and generally refers to specific details of a given machine, including its detailed logic design and packaging technology (Figure 1).

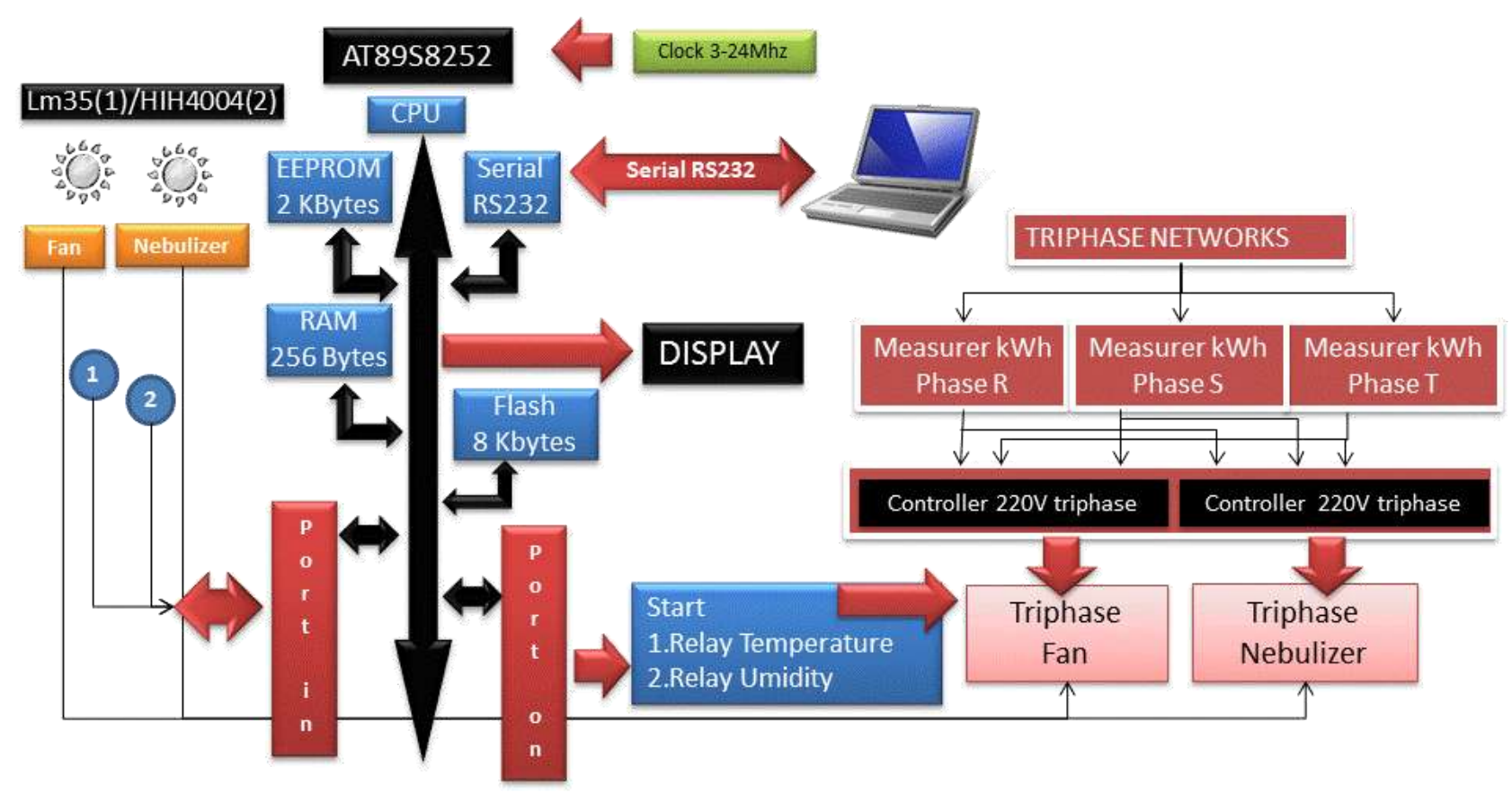

FIGURE 1. Hardware block diagram. 
The controller was composed of a metal box with dimensions of $0.13 \mathrm{~m}$ in width, $0.25 \mathrm{~m}$ long and $0.06 \mathrm{~m}$ in thickness. Within this box plates were connected to each other forming an electronic circuit, and also other components such as display, buttons, leds, switch on and off the equipment, fuse holder to protect the equipment from variations in the power supply, DB-type connectors, a DB 9 used for programming, a DB 15 that received information from sensors and a DB 25 passing information to the contactors (Figures 2 and 3 ).
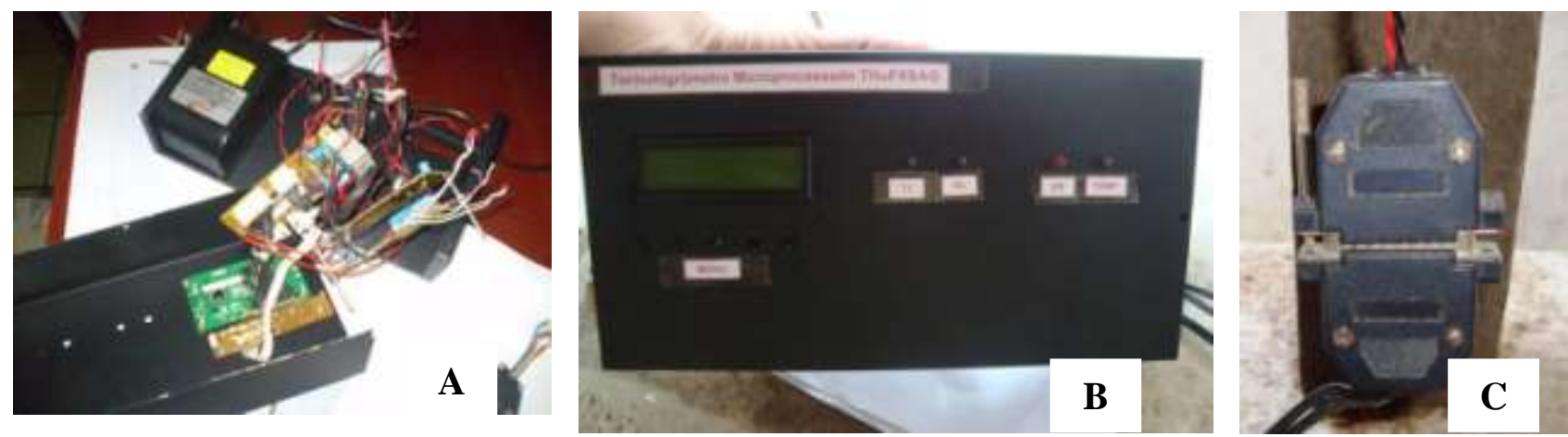

FIGURE 2. Mounting the controller (A), controller's frontal view (B), DB 25 connector for communication between the controller and the actuators $(\mathrm{C})$.
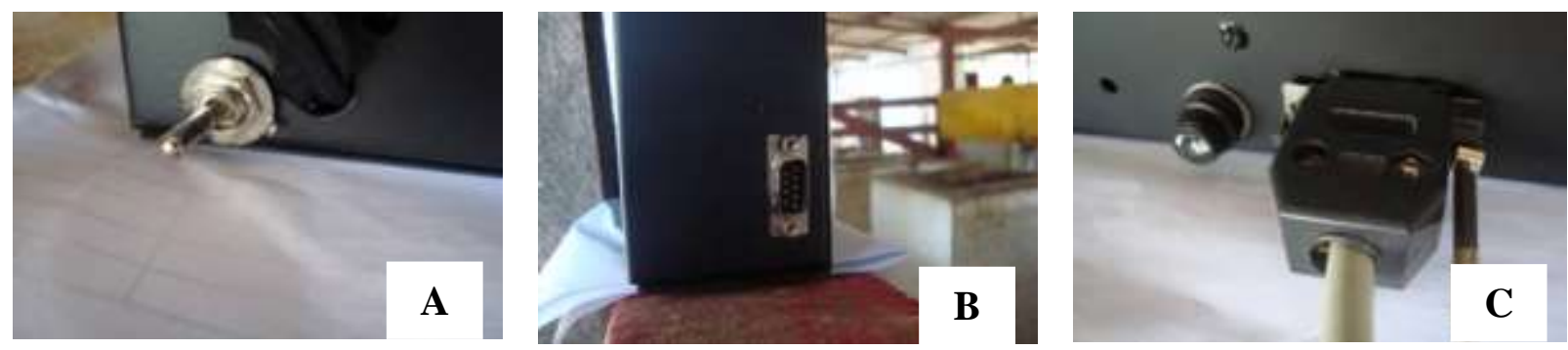

FIGURE 3. On/off switch (A), input (DB 9) for programming (B) and communication (DB 15) with sensors $(\mathrm{C})$.

The automatic controller of the environmental variables was developed in the laboratory using proto-board for testing and operational testing. The steps that proceeded to test, measurement (laboratory) and validation (in field) were performed using the HOBO Pro HB8 datalogger (Onset Computer Corporation Bourne, MA, USA) to record the dry bulb temperature (Tbs) and the relative humidity (\% RH) with subsequent comparison with the measurements performed by the controller; its operating range was between -20 and $70{ }^{\circ} \mathrm{C}(\mathrm{Tbs})$, and 0-95\% (\% RH). During the step of testing were also performed measurements of the response time between the data logger and the controller. In the validation step were compared data from the external environment, recorded at the weather station located $100 \mathrm{~m}$ from the waiting corral, with the data obtained by the controller in the internal environment (waiting corral).

The validation step of the controller system performed in the waiting corral, equipped with evaporative cooling system (AEC), was composed of two axial fans trademark Ventiave ${ }^{\circledR}$, P3DPlus, $1.0 \mathrm{~m}$ in diameter, $0.5 \mathrm{HP}$ three-phase motor, $240 \mathrm{~m}^{3} \mathrm{~min}^{-1}$ flow rate, $965 \mathrm{RPM}$, and $2.5 \mathrm{~m} \mathrm{~s}^{-1}$ speed of air mass displacement. In the waiting corral these fans were fixed on the south face at $6 \mathrm{~m}$ spacing from the equipment, $2.5 \mathrm{~m}$ height from the floor (measured from the equipment center) and $20^{\circ}$ inclined to the vertical towards the floor (Figure 4).

The spraying system was composed of five lines (polyethylene pipe), with four nebulizer nozzles per row, Asbrasil brand, 7110 Hadar model, $1.5 \mathrm{~m}$ spacing between rows and nozzles at 3 $\mathrm{m}$ from the floor. This system had a centrifugal pump Schneider® brand, model BC-92SK, $0.75 \mathrm{hp}$ and three-phase motor, whose energy consumption was equivalent to $0.65 \mathrm{kWh}$. The water flow in the nebulizer lines was $240 \mathrm{~L} \mathrm{~h}^{-1}$ (Figure 4). 


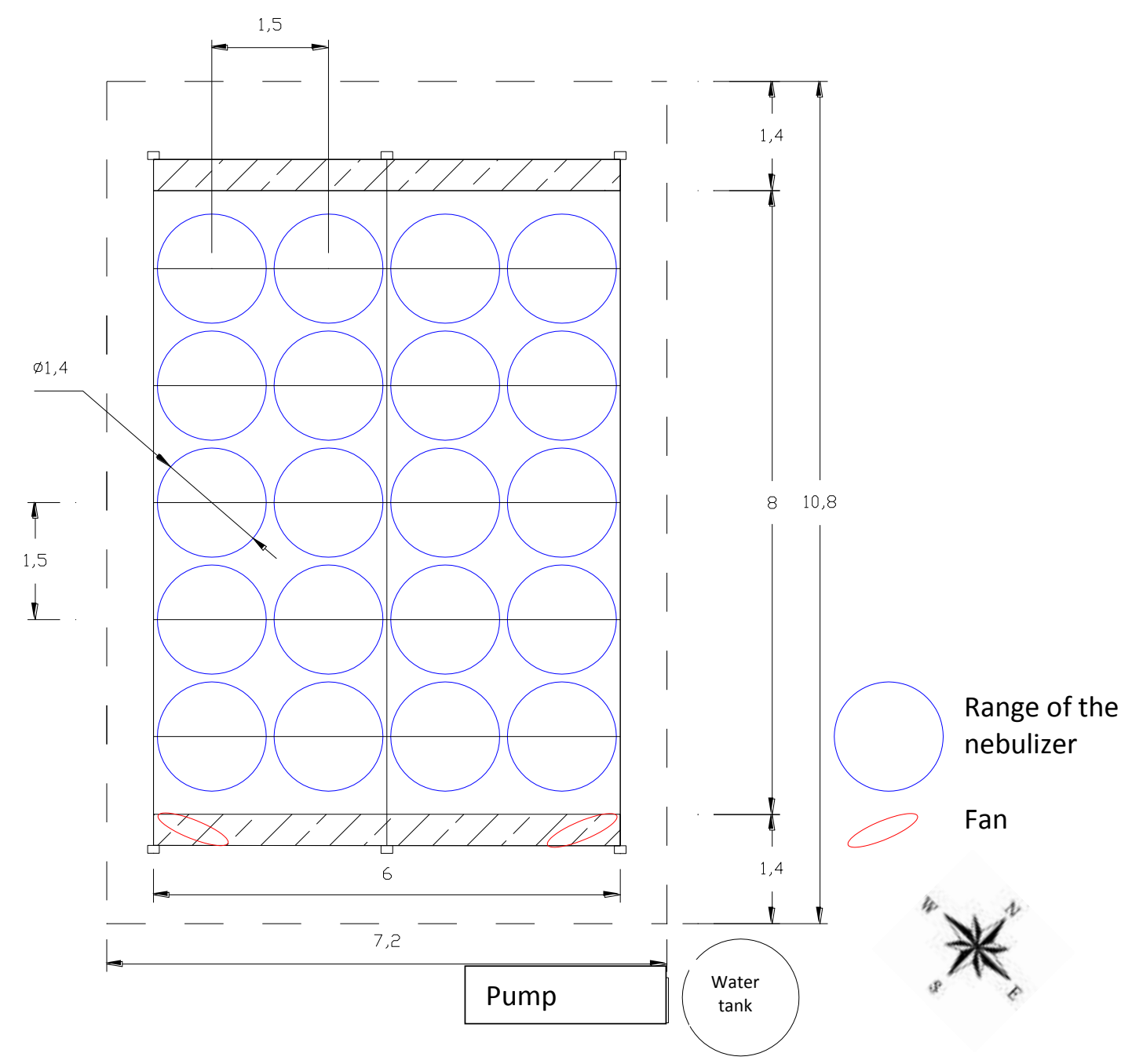

FIGURE 4. Waiting corral ground floor and location of fans and nebulization lines.

The controller system was based on specific parameters of relative humidity and temperature, enabling significant reductions in operations and cost of electronic devices. It was used semiconductor sensors (LM35) ranging up to $0.25{ }^{\circ} \mathrm{C}$, within the temperature range of $-55^{\circ} \mathrm{C}$ to $150{ }^{\circ} \mathrm{C}$ and $\mathrm{HIH}-4004$ sensor series, with changes of $0.5 \%$ within the range of relative humidity of $0-90 \%$ and variations of up to $3 \%$, when exposed to humidity above $90 \%$. These sensors had low output impedance, linear tension and inherent calibration, causing the reading interface was simple, reducing the cost of the whole system.

The equipment operated as follows, data recorded by the temperature (LM35) and relative humidity (HIH-4004) sensors were sent to the controller in the form of signal through a sleeve-like cable connected to the device in a DB 15 entry. The display initialization occurred; carrying an input image and then 3 seconds after displayed the screen of signal acquisition. It was performed the calculation of the pixel to be shown on the display corresponding to the analog value. Data referring to acquired signal were sent to the computer through the serial interface. The microcontroller interpreted such data and triggered or deactivated the actuators (fans and nebulizers) depending on the programming provided by the user.

To avoid false readings, the sensors were housed in an open white container at the bottom for air circulation, once the sensors were exposed directly to solar radiation, nebulization and ventilation could alter the reading and thus lead to the controller's malfunction.

The SRAE was connected to a power panel and triggered automatically by the controller, which enabled operating the system intermittently, during the stay of animals in the waiting corral. 
The fans and centrifugal pump were triggered when the temperature exceeded $26.0{ }^{\circ} \mathrm{C}$ and relative humidity was below $65 \%$, respectively.

To turn off the system was used the hysteresis of 1 (one) unit, for both temperature and humidity, i.e., the controller is programmed to turn off the fans and centrifugal pump when the ambient temperature reached an unit below $26.0{ }^{\circ} \mathrm{C}\left(25^{\circ} \mathrm{C}\right)$ and a relative humidity unit above $65 \%$ (66\%), respectively.

\section{Technical features of the proposed controller:}

- Power voltage: 8 to 15 VDC;

- Consumption: 61/81 mA with relays off, $198 \mathrm{~mA}$ with 2 relays operated;

- Capacity for up to 10 sensors: (requires hardware adjustments);

- Configurable sensors Inputs (temperature and humidity);

- Settings "preset" and hysteresis via the serial port;

- Sensitivity of inputs: $1.275 \mathrm{~V}$ (full scale);

- Temperature range: $0{ }^{\circ} \mathrm{C}$ to $127.5{ }^{\circ} \mathrm{C}$ in steps of $0.5{ }^{\circ} \mathrm{C}$;

- Humidity range: 0 to $100 \%$ in steps of $0.5 \%$;

- Time between measurements (approximate): $8 \mathrm{~s}$;

- Automatic or manual advance of sensors;

- 16x2 LCD display with green backlight and on / off options;

- Keyboard with functions to reset, menu, exit, forward and backward;

- RS232 serial communication with easy interface with the terminal hyper or other terminal emulator (4800-8-n-1);

- Configurable via serial port;

- Microcontroller AT89S8252 INTEL MCS-51, with 8 Kbytes of Flash memory, 256 Bytes of RAM memory, 2 Kbytes of EEPROM memory, an USART interface, 3 timers/counters.

\section{Programming the controller}

To start programming was necessary to perform some steps to set the terminal "hyper" and then the Windows creates a serial connection. The programming was conducted by means of RS232 serial communication (DB 9 connector) of simple interface using the terminal "hyper".

There were two initial options in the programming environment, in which the key 1 (a) started up and the 0 (zero) interrupted data transmission. After initiated the data transmission, it was used the C key to set the "preset" values (set value) and temperature hysteresis. In the "preset" configuration and hysteresis the adjust value of environmental variable with three figures without commas was typed (e.g. 285 to designate $28.5^{\circ} \mathrm{C}$ ) and subsequently the same procedure was performed for setting the environmental variable air humidity.

After running all settings, it used the S key to save the changes; otherwise the settings would be lost when the equipment was turned off (Figure 5).

\section{Commands for programming by the serial port}

$\mathbf{1}$ - enables the data transmission

0 - disables data transmission

A - switches to automatic mode

M - switches to manual mode 
B - Turn on/off the display backlight

$>$ - Forwards the sensor

$<-$ Rewards the sensor

H - Reading helps

T - Back to the first sensor

$\mathbf{S}$ - Save current settings in nonvolatile memory

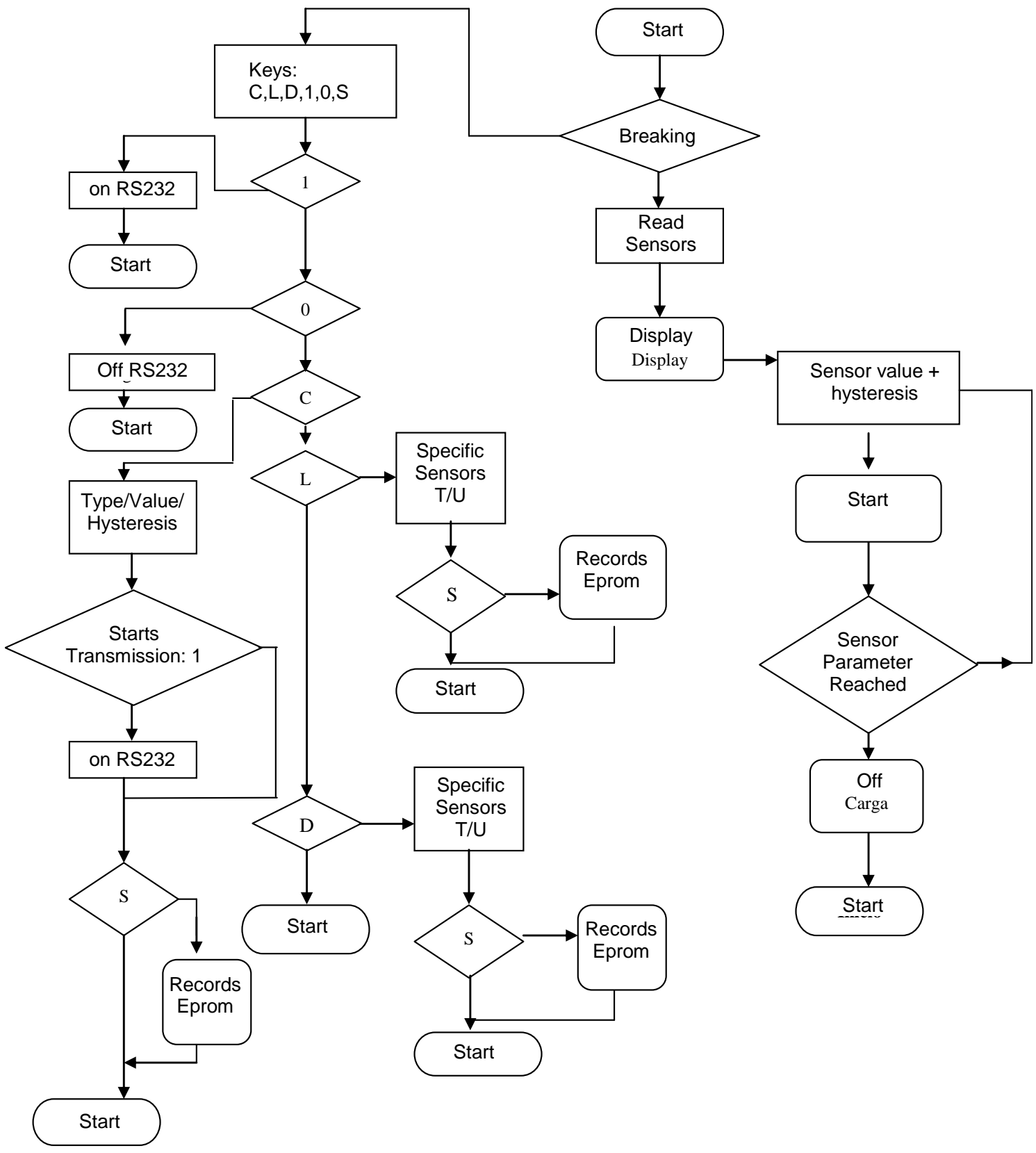

FIGURE 5. Block diagram of operating software.

\section{RESULTS AND DISCUSSION}

The testing step performed in laboratory showed that the functional relationship obtained by linear regression was acceptable, which showed coefficient of determination $\left(\mathrm{R}^{2}\right)$ equal to 0.76 and 0.86 for temperature (Figure 6) and relative humidity (Figure 7) respectively, based on the reference data recorded by the datalogger and the data obtained by monitoring the controller system. 
Results of the test step indicated the need for calibration with setting of the controller programming (Figure 6 and 7). This result was associated with two concurrent causes: different response times of instruments, making each one provide values of different humidity and temperature by not being in balance and, the interference due to lack of protection for the controller sensors.

To measurements of air temperature, sensors should be protected from solar radiation during the day and from cooling caused by long-wave radiation at night. The temperature differences between air and sensors are the main causes of measurement error. The protections with forced air circulation significantly reduce measurement errors, but the protections with natural ventilation are also effective forms of protection (MCKAY \& MCTAGGERT-COWAN, 1977).

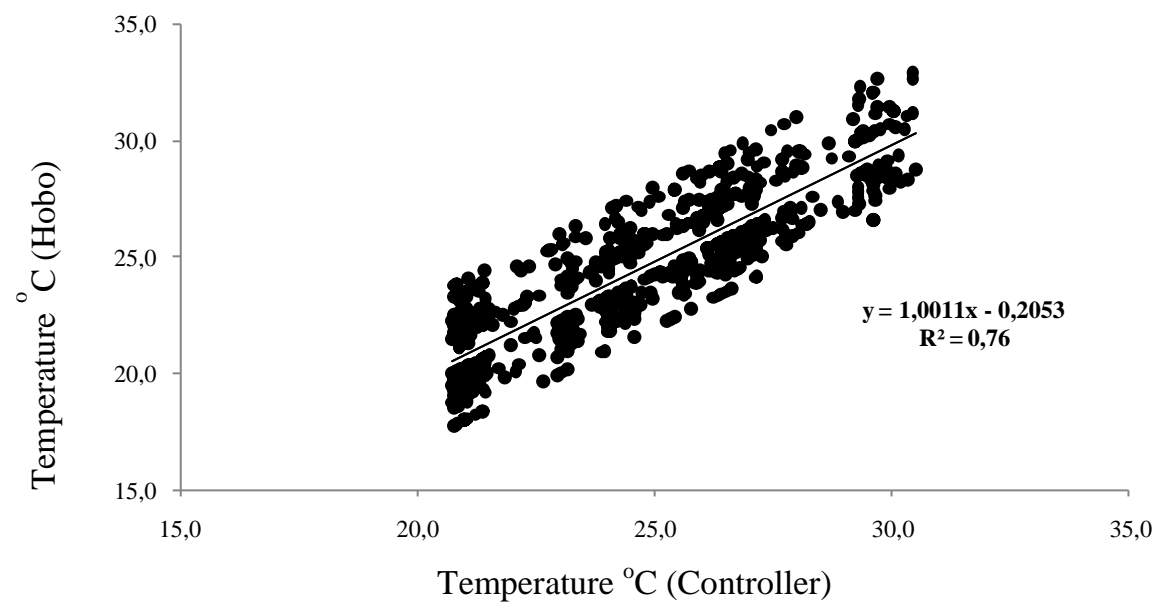

FIGURE 6. Functional relationship among air temperature data obtained in the laboratory by the data logger and controller in the test step.

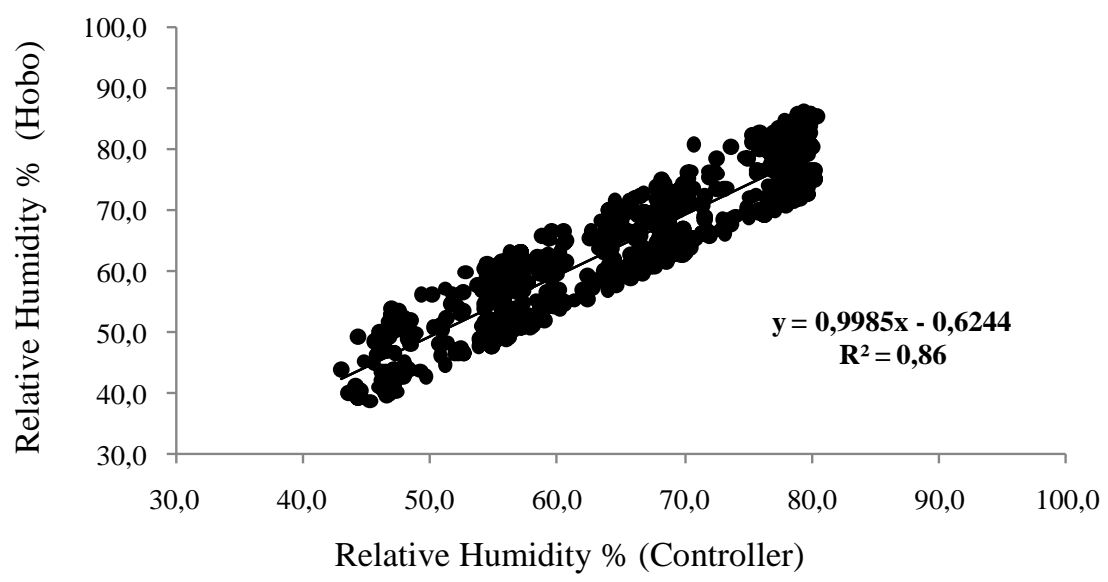

FIGURE 7. Functional relationship among relative humidity data obtained in the laboratory by data logger and controller in test step.

Given the results obtained during the test step (Figure 6 and 7), in the measurement step was tried to solve these barriers, retracing the programming to make their readings simultaneous with the datalogger, the controller sensors distribution under shelter allowed better adjustment between the equipment getting $\mathrm{R}^{2}$ values of around 0.97 and 0.96 for temperature (Figure 8) and relative humidity (Figure 9) respectively. 


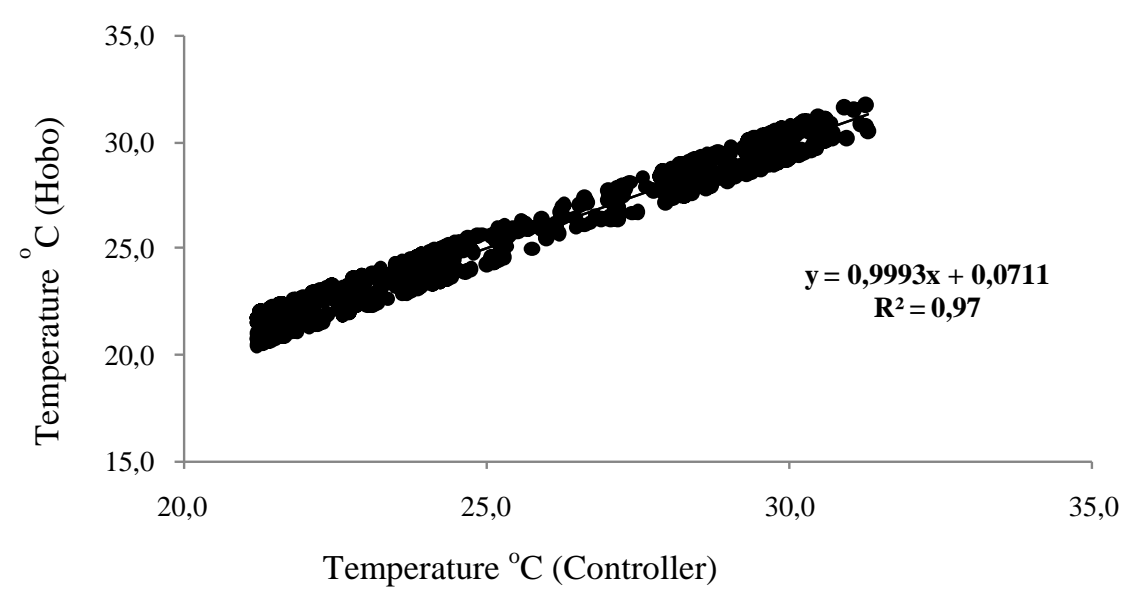

FIGURE 8. Functional relationship among air temperature data obtained in the laboratory by data logger and controller in the measurement step.

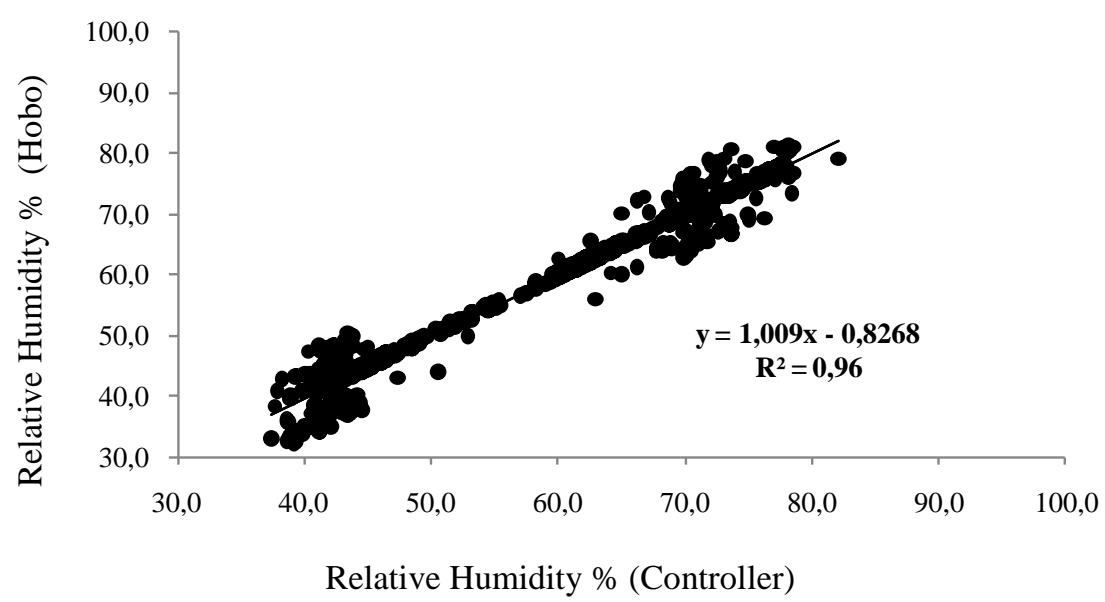

FIGURE 9. Functional relationship among relative humidity data obtained by the data logger and controller in the measurement step.

The validation step conducted at the waiting corral after the necessary changes to the equipment in the laboratory, there was an optimum adjustment between the data recorded by the datalogger and the controller system, with $\mathrm{R}^{2}$ values of around 0.95 and 0.94 for temperature (Figure 10) and relative humidity (Figure 11) respectively. These results corroborate those obtained by Silva et al. (2007) who developed an automated system for data acquisition on relative humidity and found a coefficient of determination 0.99, compared with the conventional instrumentation.

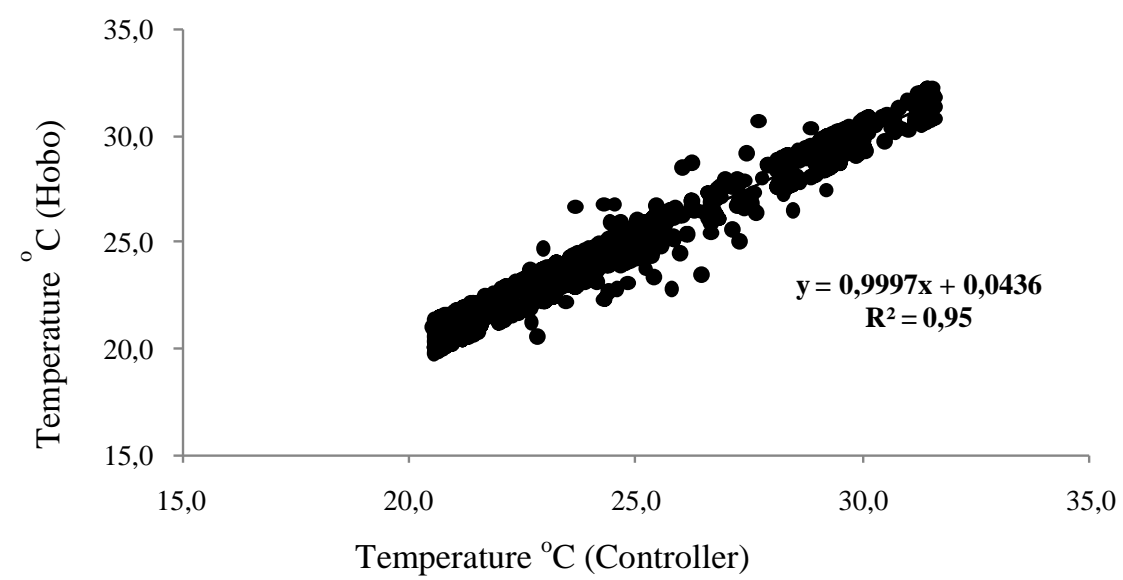

FIGURE 10. Functional relationship among air temperature data obtained by the data logger and controller in the validation step. 


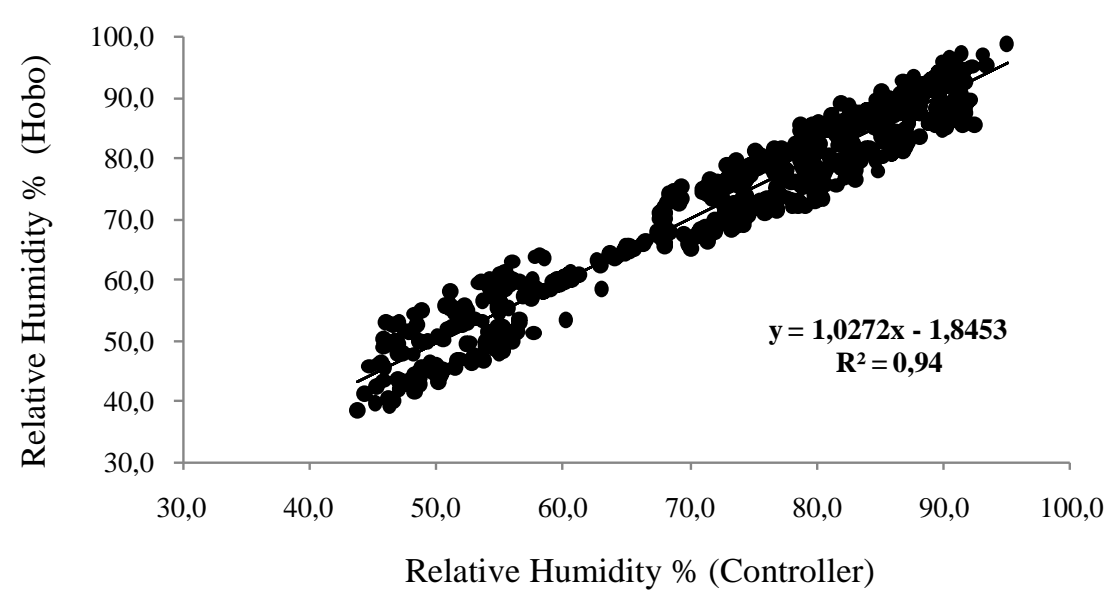

FIGURE 11. Functional relationship among relative humidity data obtained by the data logger and controller in the validation step.

This step showed coefficients of determination very close to those on the previous step, confirming that the product was shown to be effective not only in laboratory conditions, but also in the field. After $40 \mathrm{~min}$ of acclimatization in the waiting corral, the equipment proved to be effective in controlling the ambient temperature, keeping it below the critical temperature exceeding $26{ }^{\circ} \mathrm{C}$ (PERISSINOTTO \& MOURA, 2007), with mean of $25.09{ }^{\circ} \mathrm{C}$, in addition to ensure the degree of automation necessary for the intermittent operation of the actuators (Figure 12).

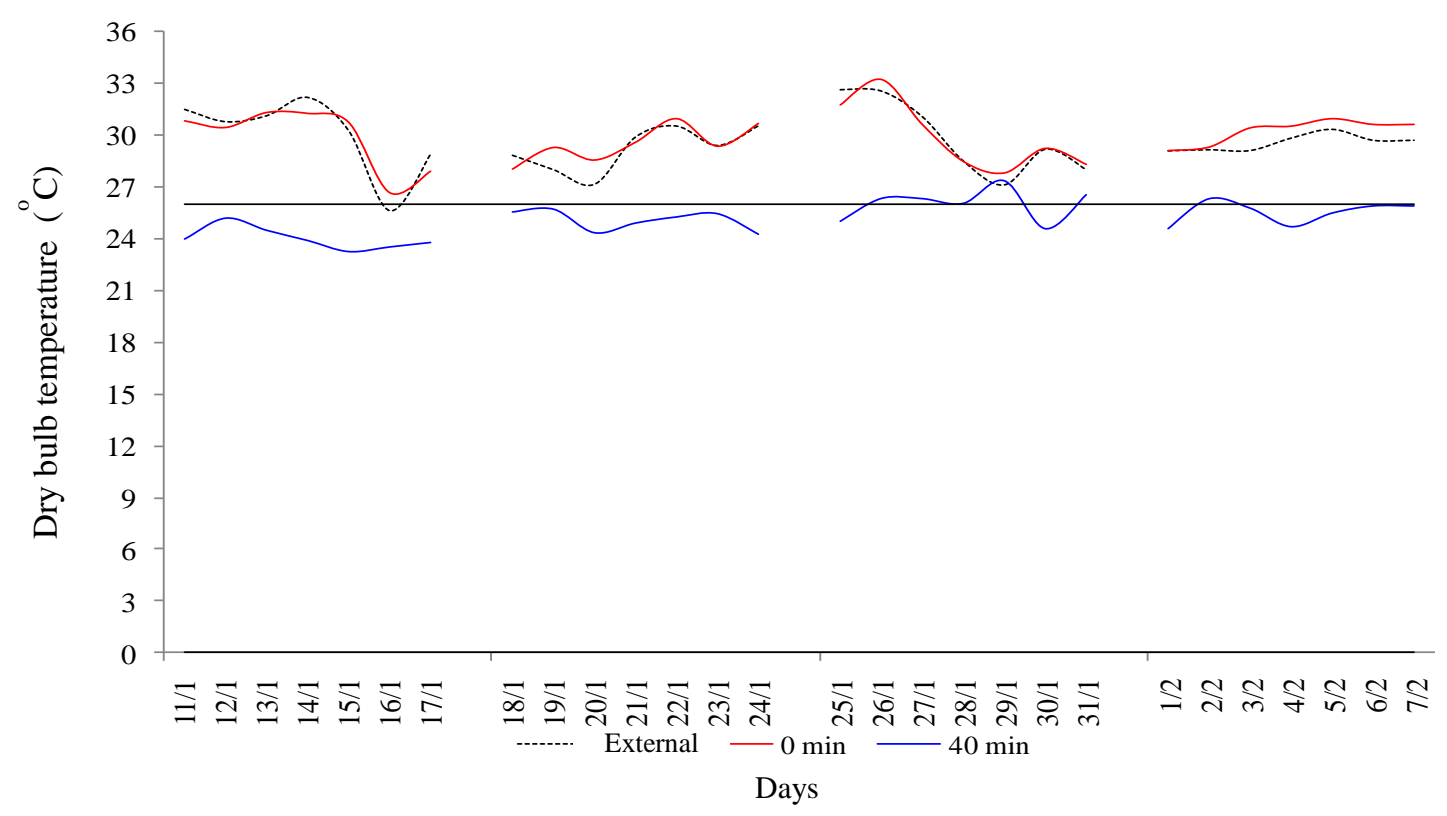

FIGURE 12. Variation of dry bulb temperature after $40 \mathrm{~min}$ of air conditioning and under weather station (outdoor) in the afternoon ( $13 \mathrm{~h} 30 \mathrm{~min}$ to $14 \mathrm{~h} 10 \mathrm{~min}$ ).

The controller cost including manpower and all the electronic components needed for its operation was $\mathrm{R} \$ 325.76$ (Table 1). In comparison with other systems already on the market such as digital controller for temperature and relative humidity whose model has two channels, one channel for temperature and another for relative humidity, requires investment of approximately $\mathrm{R} \$ 453.00$, i.e., higher cost of $\mathrm{R} \$ 127.24$ compared with the prototype developed in this study. 
TABLE 1. Cost analysis of the temperature and humidity controller.

\begin{tabular}{lccc}
\hline Initial Investment & Quantity & Unit Value (R\$) & Total Value (R\$) \\
\hline Controller* & 1 & 293.39 & 293.39 \\
Sensor LM35 & 1 & 3.87 & 3.87 \\
Sensor HIH-4004 & 1 & 19.80 & 19.80 \\
Sleeve-type cable & 2 & 4.35 & 8.70 \\
\hline Total R\$ & & & 325.76 \\
\hline * Incing
\end{tabular}

* Including manpower and all the components necessary for operation.

\section{CONCLUSIONS}

The controller system can be safely used in monitoring and controlling environmental variables, temperature and air relative humidity, ensuring the degree of automation required to the intermittent actuation of the actuators in the environmental control for dairy cattle.

The developed device presented lower cost than the mean of other models on the market.

\section{REFERENCES}

ALVAREZ, J.; NUTHALL, P. Adoption of computer based information systems the case of dairy farmers in Canterbury, NZ, and Florida, Uruguay. Computers and Electronics in Agriculture, Bornsesteeg, v.50, n.1, p.48-60, 2006.

ARCARO, J.R.P.; ARCARO JUNIOR, I.; POZZI, C.R.; MATARAZZO, S.V.; DIB, C.C; FAGUNDES, H.; COSTA, E.O. Efeitos do sistema de resfriamento adiabático evaporativo em freestall sobre as respostas fisiológicas de vacas em lactação. Boletim de Indústria Animal, Nova Odessa, v.63, p.209-215, 2006.

BOTEGA, J.V.L.; BRAGA JÚNIOR, R.A.; LOPES, M.A.; RABELO, G.F. Diagnóstico da automação na produção leiteira. Ciência Agrotécnica, Lavras, v.32, n.2, p.635-639, 2008.

MATARAZZO, S.V.; SILVA, I.J.O.; PERISSINOTTO, M.; FERNANDES, S.A.A. Intermitência do sistema de resfriamento adiabático evaporativo por aspersão em instalação para vacas em lactação. Engenharia Agrícola, Jaboticabal, v.26, n.3, p.654-662, 2006.

MCKAY, D.J.; MCTAGGERT-COWAN, J.D. An intercomparison of radiation shields for auto stations. World Meteorological Organization, Geneve, n.480, p.208-213, 1977.

NASH, E.; DREGER, F.; SCHWARZ, J.; BILL, R.; WERNER, A. Development of a model of data-flows for precision agriculture based on a collaborative research project. Computers and Electronics in Agriculture, Bornsesteeg, v.66, n.1, p.25-37, 2009.

PERISSINOTTO, M.; MOURA, D.J. Determinação do conforto térmico de vacas leiteiras utilizando a mineração de dados. Revista Brasileira de Engenharia de Biossistemas, Campinas, v.1, n.2, p.117-126, 2007.

SILVA, K.O.; MORAES, S.O.; MIRANDA, J.H.; PALMIERI, A.M. Sistema automatizado para aquisição de dados de umidade relativa do ar. Engenharia Agrícola, Jaboticabal, v.27, n.3, p.630638, 2007.

SORENSEN, C.G.; FOUNTAS, S.; NASH, E.; PESONEN, L.; BOCHTIS, D.; PEDERSEN, S.N. Conceptual model of a future farm management information system. Computers and Electronics in Agriculture, Bornsesteeg, v.72, n.1, p.37-47, 2010.

WATHES, C.M.; KRISTENSEN, H.H.; AERTS, J.M.; BERCKMANS, D. Is precision livestock farming an engineer's daydream or nightmare, an animal's friend or foe, and a farmer's panacea or pitfall? Computers and Electronics in Agriculture, Bornsesteeg, v.64, n.1, p.2-10, 2008. 